\title{
Venn-diagram strategy in EFL class to enhance learners' writing skill and motivation
}

\author{
Muhammad Lukman Syafii ${ }^{1}$, M. Zaini Miftah ${ }^{2}$ \\ ${ }^{1}$ Accounting Department in Business English, Faculty of Economics, Universitas \\ Muhammadiyah Ponorogo, Jawa Timur, Indonesia \\ ${ }^{2}$ Department of English Language Education, Faculty of Teacher Training and Education, \\ Institut Agama Islam Negeri Palangka Raya, Kalimantan Tengah, Indonesia \\ ${ }^{1}$ muhammadlukmansyafii@umpo.ac.id (corresponding author) \\ ${ }^{2}$ m.zaini.miftah@iain-palangkaraya.ac.id
}

\begin{abstract}
This classroom action research was intended to enhance students' skills and motivation in writing report texts by implementing the Venn-diagram strategy. Twenty-one students failing to achieve the passing grade level of scores on their writing skills at the ninth grade of an Islamic secondary school in East Java Indonesia became the subjects of the study. The observation checklist, field notes, questionnaires, and writing test were used to collect data through implementing the Venn-diagram strategy taking a two-set circle and applying the writing process - prewriting via generating ideas, selecting relevant ideas, and ordering ideas; drafting general classification and description paragraphs; revising the rough draft and editing it; and publishing a final version. The results showed that the strategy can enhance the learners' skills and their motivation in writing report text. The learners' writing scores significantly increased both in two cycles - thirteen learners of the twenty-one students passed from the passing grade level in Cycle 1, and all learners passed from those in Cycle 2. It also highly motivates learners in writing report text, both in two cycles. Therefore, English teachers are recommended to apply Venndiagram strategy in EFL writing class to start writing.
\end{abstract}

Keywords: Venn-diagram strategy; writing skill; learner motivation; Indonesian EFL writing class; report text 
How to cite this paper (in APA style): Syafii, M. L., \& Miftah, M. Z. (2020). Venn-diagram strategy in EFL class to enhance learners' writing skill and motivation. Journal on English as a Foreign Language, 10(1), 141-162. https://doi.org/10.23971/jefl.v10i1.1556

DOI: https://doi.org/10.23971/jefl.v10i1.1556

cc) (i) (2)

The increase of use of English as a lingua franca in the globalization era contributes to the enhancement of use of L2 writing particularly for people in English as a foreign language (EFL) context (Khalili, 2018) such as Indonesian EFL context. One of the language skills that must be acquired by Indonesian EFL students is writing skill. It is since writing is considered a productive skill and the activities leading to written products in the process of EFL learning (Sa'diyah \& Cahyono, 2019), and moreover, it is the most challenging skill to master (Ahmadi \& Besharati, 2017; Al-Shaer, 2014). In addition, writing in an EFL context is complicated process in the development of the ideas to produce writings with the characteristics of linguistics features of their language target they have never had (Al-Shaer, 2014; Byrd, 2016).

It has been acknowledged that writing is not only content-oriented but also involves various rhetorical strategies. They can help writers project on the texts so that the content and the writers' stance as well can be understood (Musa et al., 2019). In writing activities, some students prefer to learn by obtaining information from books or newspapers, and the others prefer a verbal explanation or lecture (Hanjani, 2019). Therefore, writing activity should be supported by several theoretical arguments including the process-oriented approach to writing (Miftah, 2005; Shi, 1998; Sorenson, 2010; Suherman, 2018).

In the context of teaching EFL for junior high school in Indonesia, based on the English curriculum for junior high school, particularly the ninth graders, students have to master two kinds of texts - report and narrative texts (Ministry of Education and Culture of the Republic of Indonesia, 2013, p. 66). Following the curriculum, writing report text should be taught in the school level. However, writing report text in the school is one of the difficult language skills to achieve since the students need to have enough language and general intellectual skills to generate and organize ideas and put the ideas into coherent, logically ordered, intelligible sentences, paragraphs, and essays. Lack of either grammar competence or vocabulary, in particular, makes learners

Journal on English as a Foreign Language, 10(1), 141-162

Copyright ( 2020 by JEFL, p-ISSN 2088-1657; e-ISSN 2502-6615 
difficult to produce not only a paragraph but also a sentence, even (Hidayati, 2018; Simpson, 2006).

Based on the preliminary study at the EFL class of a junior high school by taking the writing report score of the ninth graders at the Islamic junior high school (MTs Al-Islam) Nganjuk, East Java, Indonesia, it was found that the result was unsatisfactory. Out of twenty-six students, only three students $(11.54 \%)$ had writing score equal to the passing grade level, two students $(7.69 \%)$ had scored above the passing grade level, and the rest, twenty-one students $(80.77 \%)$ had score below the passing grade level.

A deep analysis of the students' writing showed that most of the students' report texts were not completed with a clear topic sentence. Although their texts were completed with a clear topic sentence, they lost of details or the details were not related to the topic itself. Besides, their report texts were not organized well. The position of the general classification and the description paragraphs was not clear enough. Moreover, the vocabulary items that the students used in their report texts were not appropriate with the content of the report text. The other problems in the students' writing were their grammar including the word order and tense and their mechanics covering the spelling, capitalization, and punctuation.

Furthermore, the pre observation result showed that most of the students had low motivation in writing English. There is a consensus among learners, educators, teachers, material developers, and scholars that motivation plays a crucial role in obtaining mastery over a second or foreign language (Amjadiparvar \& Zarrïn, 2019). It showed that they were fearful, coerced, and not confident in joining writing class. They did a writing task due to pursuing a present from their English teacher. Besides, they were not enthusiastic, not a spirit, and not joyful in doing writing tasks from the teacher. However, in the writing classroom, it is expected to each student's motivation for success and fear of failure and to assess their willingness to implementing writing strategy into the educational process and their expectations (Malinina, 2013). Also, the interview results with the English teacher showed that the writing strategy applied in the class had not solved the students' problems in writing. In short, the teaching of writing report text has two issues - the students' ability in writing report text and their motivation in writing class.

In deciding the teaching strategy to apply, it is necessary to consider materials such as report text which should be aware of the general definition and the classification of each subject students intend to write. Thus, the closest

Journal on English as a Foreign Language, 10(1), 141-162

Copyright @ 2020 by JEFL, p-ISSN 2088-1657; e-ISSN 2502-6615 
strategy to cover teaching how to write report text was a Venn-diagram strategy since it enables students to organize thoughts or textual quotations before writing. It is as suggested by Samosir and Sibarani (2012) that Venn-diagram is a very good strategy to be applied in the classroom practice to improve students' academic performance. By applying the strategy, students get involved to search for the target issues in relation with their background knowledge that enables them to develop the ideas supported with the details in a paragraph (George \& Palilonis, 2006; Junaid, 2012; Samosir \& Sibarani, 2012; Siregar, 2018).

The term "Venn Diagram" was first introduced by John Venn and published in 1880 to teach mathematical concepts. But, today's Venn-diagram use is expended to other subjects such as science, economic and English. According to George and Palilonis (2006), Venn-diagram is developed with two or more overlapping circles to introduce the connection of the sets. The present study applied Venn-diagram strategy as a learning tool to assist the students in searching ideas before writing. Basically, the Venn-diagram is simple for graphic organizer strategy to develop writing organization and students' knowledge in writing (Eltahir et al., 2019; Samosir \& Sibarani, 2012; Siregar, 2018).

In language arts instruction, Venn-diagram can be applied during the instruction activities. Venn-diagram is useful for examining similarities and differences written in the shape of circles and similarities are shown in the overlapping circle (Junaid, 2012). In prewriting activities, it provides an interaction in which teacher scaffold learners in class discussion to organize their ideas, or learners assist peers to generate ideas for their writing assignments (Shi, 1998). It assists students to organize their thought, correlate the texts and their prior knowledge, and organize similarities and differences visually (George \& Palilonis, 2006; Rama, 2018; Ruskey \& Weston, 2011). Therefore, Venn-diagram can be used to develop the students' thoughts to write.

The report text is a text asking for straight information, arranged in some logical orders and to discuss different points of view about a subject to present one side, the other, and finally come down on one side. Venn-diagram could explore learners writing skills to write report texts in prewriting activities because it solves students' problems to organize thoughts or textual quotations before writing (Mustika \& Adnan, 2019; Ruskey \& Weston, 2011). It also contributes to keeping students actively involved and allows students to organize their ideas about the concepts (Junaid, 2012).

Journal on English as a Foreign Language, 10(1), 141-162

Copyright (C) 2020 by JEFL, p-ISSN 2088-1657; e-ISSN 2502-6615 
Research has been conducted to investigate Venn-diagram strategy in the EFL classroom and particularly in writing class. Dean and Grierson (2006) investigated re-envisioning reading and writing through combined-text picture books. The result showed that the writing process using a graphic organizer in the form of Venn-diagram encouraged students to find a topic after which teachers can begin helping students through the inquiry and investigation preparing them to write. Another study, Mustika and Adnan (2019) reported that the students' problem on finding a topic for writing was solved by using the Venn-diagram strategy. It also could help students organize ideas orderly by compiling their neatly and reduce their habits of using a messy draft to collect their ideas.

It seems that the current study has a similar to the previous ones. However, the study was different in terms of writing problems faced by the ninth graders of the Islamic secondary school that the students did not understand how to get easily started to write report text. The study would develop how Venn-diagram strategy can be applied for the context of EFL writing class at the ninth graders of the Islamic secondary school. Therefore, the research problem of the present study is, "How can Venn-diagram strategy be applied in EFL class to enhance learners' skill and motivation in writing report text." Meanwhile, the study was aimed at developing Venn-diagram strategy to enhance learners' skill and motivation in writing report text.

The Venn-diagram strategy going along with the writing process through the activities of prewriting, drafting, revising, editing, and publishing (Miftah, 2015; Tompkins \& Hoskisson, 1995) would significantly contribute to the development of teaching and learning writing at the school. It hopes the students could improve their score in writing report text in terms of the aspects of writing - content, organization, grammar, vocabulary, and mechanics. Also, it could increase their motivation in the writing process so that they are not fearful, not coerced, and always confident in writing class.

\section{METHOD}

\section{Research Design}

The study applied the classroom action research adapted from Kemmis \& McTaggart's (1992) model via the steps - planning, implementing, observing, and reflecting. It was to develop the Venn-diagram strategy that can be applied in EFL class to enhance learners' writing skill and motivation. The design is applicable because, within the model, a new cycle covering those stages can be

Journal on English as a Foreign Language, 10(1), 141-162

Copyright (C) 2020 by JEFL, p-ISSN 2088-1657; e-ISSN 2502-6615 
re-implemented if satisfactory results of the teaching and learning process are not achieved. Classroom action research aims to develop an innovative instructional strategy that can assist to enhance students' success in learning English (Latief, 2012). This research was conducted at the Islamic junior high school (MTs Al-Islam) Nganjuk, East Java, Indonesia. Twenty-one students of the ninth grade who failed to achieve the passing grade level of scores on their writing report became the subjects in the study.

\section{Data Collection}

The data collection was carried out during the implementation of Vennstrategy in EFL class. In implementing the strategy, some steps adapted from Sorenson (2010) were taken during the process of writing report text. The process covers how to get ideas, how to put them together, how to get them on the paper, and how to polish them into a piece of writing. To collect the data, it was through the techniques of observation, questionnaire, and test. It was developed the research instruments - observation checklist, field notes, questionnaire, and writing test.

The observation checklist was used to observe how well the Venndiagram strategy enhanced the students to write a report text. It obtained the data about the Venn-diagram strategy implementation through the writing process by following Tompkins and Hoskisson's (1995) model of the stages prewriting, drafting, revising, editing, and publishing. Meanwhile, field notes were used to document significant changes throughout the research which might be uncovered in the observation checklist. It contained the strength and the weaknesses of the teaching and learning process as well as the suggestions that covered the setting of the class, the interaction among the students, between the students and the teacher, and everything happened unpredictably during the Venn-diagram strategy implemented in the EFL class.

The questionnaire was employed to collect a range of information about the students' motivation based on their responses after administering the Venndiagram strategy for teaching and learning of writing report text. The questionnaire consisted of 20 items (see Appendix). Its responses consisted of categories: (a) "always" means very high, (b) "often" means high, (c) "sometimes" means fair, (d) "rarely" means low, and (e) "never" means very low (see Appendix).

Journal on English as a Foreign Language, 10(1), 141-162

Copyright @ 2020 by JEFL, p-ISSN 2088-1657; e-ISSN 2502-6615 
The writing test was administered to gain data dealing with the students' writing achievement. The students were assigned to write a report text in the form of paragraph.

\section{Data Analysis}

To analyze the data, it was categorized into two-data classification - the data of writing achievement and motivation. To analyze the data associated with students' writing achievement; it was through analytic scoring rubric adapted from Brown (2007). Each aspect was weighted based on its worth to final product of report paragraph (scored from 1 to 4 ). The content was weighted $30 \%$ since it could be worth more than the other aspects. The organization and the grammar were weighted $20 \%$ respectively as they were worth more than vocabulary and mechanics. As there was a little anxiety around the last two aspects, vocabulary and mechanics (Bidgood et al., 2010), the small weighting was attached to them. The vocabulary and mechanical aspects were weighted $15 \%$ respectively. Also, in this study inter-rater reliability was carried out. The students' final writing scores were gained from the mean score of their individual scores taken by raters 1 and 2 . Next, the empirical validity proof was shown by presenting the empiric evidence obtained from the correlation calculation results of two rows of scores taken by the two raters. It used the Pearson product-moment correlation to find the correlation coefficient (Djiwandono, 2008). Additionally, the data of the students' writing scores were used for deciding whether the study succeeds or not by referring to the first criterion of success. It was said to be succeeded in the study if all students were able to improve their skills in writing report text by achieving the passing grade level (score 60).

The data related to the students' writing motivation obtained from the questionnaire were analyzed quantitatively based on the students' responses to the questionnaire items. The data were used for deciding whether the study succeeds or not by referring to the second criterion of success. It was said to be succeeded in the study if the students were highly motivated to write report text during the teaching and learning process. The students who had reached the quentionnaire (score 16) or above of the items of questionnaire were categorized into a high level of motivation. However, the students who had reached less than 16 were caregorized into a fail poor level of motivation.

The reflection result was furthermore used as the basic consideration to draw a conclusion whether the action stopped or needed developing. In this

Journal on English as a Foreign Language, 10(1), 141-162

Copyright @ 2020 by JEFL, p-ISSN 2088-1657; e-ISSN 2502-6615 
study, the action of implementation of Venn-diagram strategy in EFL class stopped in Cycle 2 since it met the two criteria of success.

\section{FINDINGS}

\section{Findings from Cycle 1}

\section{The students' writing achievement}

Based on the analysis of the students' writing in Cycle 1 as shown in Table 1, it shows the students' writing achievement based on the passing grade level category. Out of 21 students, there were 8 students (38\%) whose score was below the passing grade level (score 60), 13 students (62\%) whose score was above 60 , and none of them whose score was equal to 60 . This means that only 13 students can write a report paragraph in this cycle. During the Venndiagram strategy was implemented in the EFL class, two topics as the issues were developed by the students in Cycle 1 - Whether They Ever Go to Zoo and What They Usually See in the Zoo.

Table 1. The result of students' writing test in Cycle 1

\begin{tabular}{cccc}
\hline \multirow{2}{*}{ No } & Category & \multicolumn{2}{c}{ Students } \\
\cline { 3 - 4 } & (passing grade level = score 60) & Frequency $(\mathrm{F})$ & Percentage (\%) \\
\hline 1 & Below passing grade level & 8 & 38 \\
2 & Equal to passing grade level & 0 & 0 \\
3 & Above passing grade level & 13 & 62 \\
\hline
\end{tabular}

The result of data analysis also showed the category of result of the students' writing test in each aspect of writing in Cycle 1. The aspects of writing included content, organization, grammar, vocabulary, and mechanics. It is shown in Table 2.

Table 2. The result of the students' writing test in each aspect of writing in Cycle 1

\begin{tabular}{llcccccccccc}
\hline \multirow{2}{*}{ No Category } & \multicolumn{2}{c}{ Content } & \multicolumn{2}{c}{ Organization } & \multicolumn{2}{c}{ Grammar } & \multicolumn{2}{c}{ Vocabulary } & \multicolumn{2}{c}{ Mechanics } \\
\cline { 2 - 12 } & F & $\%$ & F & $\%$ & F & $\%$ & F & $\%$ & F & $\%$ \\
\hline 1 & Very good & 0 & 0 & 0 & 0 & 0 & 0 & 0 & 0 & 0 & 0 \\
2 & Good & 18 & 86 & 21 & 100 & 1 & 5 & 16 & 76 & 4 & 19 \\
3 & Poor & 3 & 14 & 0 & 0 & 13 & 62 & 5 & 24 & 1 & 76 \\
4 & Very poor & 0 & 0 & 0 & 0 & 7 & 33 & 0 & 0 & 1 & 5 \\
\hline
\end{tabular}

Table 2 depicts that 18 (86\%) students got a good score in content. Most of the students' writings were completed with a clear topic sentence. The report paragraphs produced by the students had supporting sentences that almost 
related to the topic. Besides, all students or 21 (100\%) students got a good score in term of organization. It indicates that the report paragraphs written by all students were completed with generalization and description, and arranged with almost proper connectives. Next, $16(76 \%)$ students got a good-score category in term of vocabulary. It means that most of vocabulary used in their report paragraph was understandable though there was some misuse of vocabulary and word forms. Furthermore, 4 (19\%) students got good category in a mechanics.

However, the trend problems happened were related to the writing aspects of mechanics (76\% students) and grammar (62\% students). They got a poor score in the two aspects since they still did not arrange the sentences using the correct grammar, and in mechanical aspect they faced the problems of the use of full stop, capital letter, and spelling.

The data in Table 2 is in line with the data taken from the result of the writing test on the failed students as depicted in Table 3.

Table 3. The writing scores of the failed students in the writing test in Cycle 1

\begin{tabular}{cccccccccccc}
\hline \multirow{2}{*}{ No Category } & \multicolumn{2}{c}{ Content } & \multicolumn{2}{c}{ Organization } & \multicolumn{2}{c}{ Grammar } & \multicolumn{3}{c}{ Vocabulary } & \multicolumn{2}{c}{ Mechanics } \\
\cline { 2 - 12 } & & F & $\%$ & F & $\%$ & F & $\%$ & F & $\%$ & F & $\%$ \\
\hline 1 & Very good & 0 & 0 & 0 & 0 & 0 & 0 & 0 & 0 & 0 & 0 \\
2 & Good & 5 & 63 & 8 & 100 & 0 & 0 & 3 & 38 & 0 & 0 \\
3 & Poor & 3 & 38 & 0 & 0 & 1 & 13 & 5 & 63 & 7 & 88 \\
4 & Very poor & 0 & 0 & 0 & 0 & 7 & 88 & 0 & 0 & 1 & 13 \\
\hline
\end{tabular}

Table 3 indicates that the students who were failed in writing test mostly gained a good score in the aspects of content $(63 \%$ or 5 students) and organization ( $100 \%$ or 8 students). However, most of them had poor score in term of vocabulary ( $63 \%$ or 5 students) and mechanics ( $88 \%$ or 7 students), and very poor score in grammar $(88 \%$ or 7 students). It means that the students failed due to their grammar mistakes, vocabulary, and mechanics. It happened because they did not follow the instruction given by the teacher. Vocabulary use should be developed in the revising stage while in the editing stage it should focus on the development of grammar and the mechanics. In short, the trend problems happened to the failed students were in terms of grammar and mechanics.

The findings of the students' problems in the aspects of grammar and mechanics were supported by the data obtained from the observation checklist. The analysis result pointed out that Venn-diagram strategy enhanced the 
students' writing skills in the planning, drafting, revising, and publishing stages.

In the prewriting stage, Venn-diagram helped the students to formulate a topic and to generate the topic sentence for the paragraph of the report text. Also, Venn-diagram made the students easy to develop the topic sentence and to generate some details relating to the topic sentence in the drafting stage. Besides, the Venn-diagram strategy was useful for the students to organize the general classification and the description.

In the revising stage, Venn-diagram assisted the students to revise the topic and the supporting details. However, the students got a problem in deciding the suitable words for the paragraph. It is supported by data on the field notes showing that the students needed the consideration from their peers relating to the appropriate words they had to use.

In the editing stage, most of the students did not use Venn-diagram to edit the grammar and mechanical mistakes in their report paragraphs. The finding is also in line with the data gained from the field notes. It showed that most of the students asked some repeated questions about grammar and mechanics in the meeting 3 (the editing and publishing stages) though the teacher had assisted them with editing guidelines and some explanation about the grammar and mechanic orally.

In the publishing stage, the students enjoyed the Venn-diagram and excited them to publish their writings. Most of the students enjoyed publishing their writings by reading them before the class and the rest sent them writing to the teachers' blogs.

\section{The students' motivation}

Based on the analysis of the questionnaire in Cycle 1, it shows that the students' motivation was at a high level. The 15 students responded to the questionnaire, "often". It means that the use of the Venn-diagram strategy in teaching writing report text can increase the students' motivation. In other words, the students were not fearful. They had high spirits and confidence in joining the writing class through the Venn-diagram strategy. The total score of the students' motivation is shown in Figure 1.

Figure 1 shows that the students' motivation was on the high level. The students who responded the questionnaires "often" were 15 and the rest of

Journal on English as a Foreign Language, 10(1), 141-162

Copyright @ 2020 by JEFL, p-ISSN 2088-1657; e-ISSN 2502-6615 
them (3 students) responded to the questionnaire "sometimes", while others responded the questionnaire "rarely."

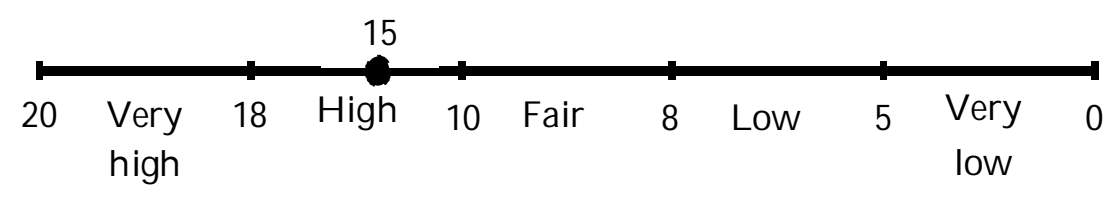

Figure 1. The students' motivation in Cycle 1

From the findings in Cycle 1, it is concluded that the Venn-diagram strategy can enhance the students' writing skills and their motivation in writing report text in the form of paragraph. However, it only increased some of the students' writing scores. It means that the Venn-diagram strategy can only achieve the second criteria of success (out of two criteria of success set up) in the study. In short, the action in Cycle 2 was needed by revising the teaching procedures in implementing the Venn-diagram strategy to overcome the students' problems.

\section{Revision of the strategy}

Based on the findings in Cycle 1, there were two main problems faced by the students relating to the implementation of the Venn-diagram strategy. The problems are in term of the activities in the revising stage focusing on the revision of the vocabulary and of those in the editing stage focusing on editing grammar and mechanics.

Results of analysis of the students' report texts show that the vocabulary items used in their writings were not an effective choice of words and word forms. The students used misuse of words though the words did not change the sentence meaning. The sentences were still understandable. For this issue, using a dictionary was still the best way. Besides, in term of grammar mistakes, it points out that the students mostly made some mistakes in the use of tense. Past verbs were used by most of the students. It seemed that the students' report paragraphs were narrative texts. Some students also made some mistakes on the subject-verb agreement such as omission of s/es for a verb after a singular subject. Next, in terms of mechanics, it indicates that the students made some mistakes on the spelling and punctuation, particularly the use of comma and dot or full stop. Some students had problems with capitalization. It means that the Venn-diagram strategy with editing guidelines was failed to assist the students to edit grammar mistakes and mechanics.

Journal on English as a Foreign Language, 10(1), 141-162

Copyright @ 2020 by JEFL, p-ISSN 2088-1657; e-ISSN 2502-6615 
To minimize the mentioned problems, the teacher-researcher and the collaborator revised the teaching procedures by proposing a mini conference between the teacher-researcher and the students in the revising and editing stages. To have a more efficient conference, the teacher-researcher made a conference with groups of the students having a similar problem so that it could focus on the students' problems in problem solving. The teacher-researcher acted as a facilitator and guide, rather than a master controller and deliver of final drafts.

\section{Findings from Cycle 2}

\section{The students' writing achievement}

Based on the analysis of the students' writing in Cycle 2 as shown in Table 4, it shows the students' writing achievement based on the passing grade level category. All students (21 students) had a score above passing grade level (score 60 ). It indicates that all students (100\%) could write a report text in form of paragraph in this cycle. During the Venn-diagram strategy was implemented in the EFL class, two topics as the issues were developed by the students in Cycle 2 -Whether They Ever Watch TV about the Animal and What Animal They See on the TV.

Table 4. The result of students' writing test in Cycle 2

\begin{tabular}{clcc}
\hline \multirow{2}{*}{ No } & \multicolumn{2}{c}{ Category } & \multicolumn{2}{c}{ Students } \\
\cline { 3 - 4 } & (passing grade level = score 60) & Frequency $(\mathrm{F})$ & Percentage (\%) \\
\hline 1 & Below passing grade level & 0 & 0 \\
2 & Equal to passing grade level & 0 & 0 \\
3 & Above passing grade level & 21 & 100 \\
\hline
\end{tabular}

Also, the result of data analysis showed the category of result of the students' writing test in each aspect of writing in Cycle 2. The aspects of writing included content, organization, grammar, vocabulary, and mechanics. It is shown in Table 5.

Table 5. The result of the students' writing test in each aspect of writing in Cycle 2

\begin{tabular}{llcccccccccc}
\hline \multirow{2}{*}{ No Category } & \multicolumn{2}{c}{ Content } & \multicolumn{2}{c}{ Organization } & \multicolumn{2}{c}{ Grammar } & \multicolumn{3}{c}{ Vocabulary } & \multicolumn{3}{c}{ Mechanics } \\
\cline { 2 - 11 } & F & $\%$ & F & $\%$ & F & $\%$ & F & $\%$ & F & $\%$ \\
\hline 1 & Very good & 6 & 75 & 8 & 100 & 0 & 0 & 3 & 38 & 2 & 25 \\
2 & Good & 2 & 25 & 0 & 0 & 8 & 100 & 5 & 63 & 6 & 75 \\
3 & Poor & 0 & 0 & 0 & 0 & 0 & 0 & 0 & 0 & 0 & 0 \\
4 & Very poor & 0 & 0 & 0 & 0 & 0 & 0 & 0 & 0 & 0 & 0 \\
\hline
\end{tabular}


Table 5 shows that most of the students got a very good score of their report paragraph writings in the writing aspects of content (75\% or 6 students) and organization $(100 \%$ or 8 students). Besides, all of them got a good score in term of grammar $(100 \%$ or 8 students). Next, most of them got a good score in terms of vocabulary ( $63 \%$ or 5 students) and mechanics ( $75 \%$ or 6 students). It means that the students' problems with grammar and mechanical aspects happened in the previous cycle had been solved in Cycle 2. Also, none of the students obtained a poor and very poor score in all aspects of writing.

Additionally, the findings of the success in solving the students' problems in the writing aspects of grammar and mechanics were supported by the data gained from the observation checklist. It points out that a mini conference conducted by the teacher-researcher and the students in the editing stage could assist the students to be actively involved in editing activities focusing on the grammar and mechanics mistakes to make better revised version of their report paragraphs. The findings are also in line with the data taken from the field notes. It informed that none of the students asked the repeated question about grammar and mechanics as happened in the previous cycle.

\section{The students' motivation}

Based on the analysis of the questionnaire in Cycle 2, it shows that the result was still given as a reinforcement statement for the finding on students' high motivation in the previous cycle. The students' motivation was on a high level with the indication that the 16 students responded to the questionnaire "often". It means that the implementation of the Venn-diagram strategy in EFL class could increase the students' motivation in writing report paragraph. In other words, the students were not fearful. But, they had high spirits and confidence in the writing activities through the Venn-diagram strategy. The total score of the students' motivation is shown in Figure 2.

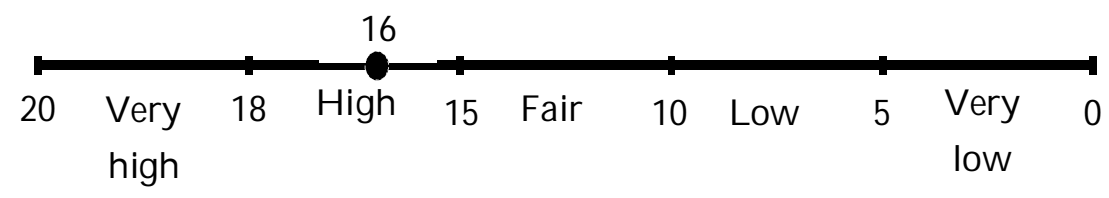

Figure 2. The students' motivation in Cycle 2

Figure 2 depicts that the students' motivation was on a high level. The 16 students responded to the questionnaire "often". The rest (4 students)

Journal on English as a Foreign Language, 10(1), 141-162

Copyright @ 2020 by JEFL, p-ISSN 2088-1657; e-ISSN 2502-6615 
responded the questionnaire "sometimes" and others responded the questionnaire "rarely."

In short, based on the findings in Cycle 2, it is concluded that the Venndiagram strategy can enhance the students' writing skills and their motivation in writing report text in the form of paragraph. It means that the implementation of the Venn-diagram strategy can achieve the two criteria of success set up in the study.

\section{DISCUSSION}

This study was investigating the use of the Venn-diagram strategy to improve the students' ability in writing report text and their motivation during the learning process. The findings showed that the Venn-diagram strategy could increase the students' writing scores and motivate students to write a report text in the form of paragraph. Based on the findings in Cycle 2, the implementation of the Venn-diagram strategy could achieve the two criteria of success set up in this study. Venn-diagram can help students who have lack of motivation in writing. Some students are not interested in writing class due to the difficulties of finding the ideas and starting to write. Through the Venndiagram, students shared their ideas by listing their ideas and filling the diagram at the same time in group. This strategy will motivate the students who do not have ideas to start writing by using the ideas they have found together (Mustika \& Adnan, 2019).

In relation with the first findings, it showed that the Venn-diagram strategy could enhance the students' skills in writing report text. The findings show that the students can produce simple report text in form of paragraph comprising general classification and description. The data in Table 5 shows that most of the students got a very good score in the writing aspects of content $(75 \%)$ and organization $(100 \%)$. Besides, all of them obtained a good score in grammar $(100 \%)$, and most of them gained a good score in vocabulary $(63 \%)$ and mechanics $(62 \%)$. This means that the students' problems related to grammar and mechanics in Cycle 1 had been solved in Cycle 2. In short, the study success was due to the teaching procedures set up by the teacher.

The Venn-diagram strategy in EFL class focused on teaching writing report text in form of paragraph has been successfully implemented. In the prewriting stage, the Venn-diagram helped the students to generate main topic of a report paragraph and develop it into a topic sentence completed with supporting details relating to the topic sentence. The circles of Venn-diagram

Journal on English as a Foreign Language, 10(1), 141-162

Copyright @ 2020 by JEFL, p-ISSN 2088-1657; e-ISSN 2502-6615 
assisted the students to construct a topic of the writing going to write. The Venn-diagram by the students made in the prewriting activity helped them to write down all their ideas as the ideas generated without constraint or formality (Friedman, 2010). The ideas in their Venn-diagram were still possible to change and modify, and to explain it better. The diagram functioned as a flowchart that can map the interactive ideas more efficient than a lengthy prose description of multiple opportunities for user choice (Friedman, 2010). Besides, the students' activity by brainstorming the ideas and putting them into Venn-diagram assists them to easily organize the ideas well.

The students easily constructed the organization of the report paragraph in the drafting stage. The drafting activity using the Venn-diagram assisted them to put the general classification and description in a right way. It prepares a visual summary of a discussion of a topic (Dean \& Grierson, 2006). The visual summary of a discussion allowed the students to interact with text ideas, considered them from different points of view, and conversed internally about them (Kucan \& Beck, 2003). The students can develop the topic in the Venndiagram into some details from some points of view and move any unrelated details to have well-organized drafts (Dean \& Grierson, 2006; Kucan \& Beck, 2003).

In the revising stage, it assisted the students revise the content of their report paragraphs. The Venn-diagram functioned as the source of a report to revise the draft. The students grouped some sentences based on the topic in each circle so that the topic sentence and the details were related to each other. Besides, group of the sentences helped the students to revise the paragraph organization of the general and description and by using the Venn-diagram it provided visualization to sort their items.

In the editing stage, the Venn-diagram with the editing guidelines did not work well to students' activities focusing on the grammar and mechanics in Cycle 1. It was different from the results of the research done by Miftah (2015) and Syafii (2017) stating that by using editing guidelines it can edit a model of rough draft step-by-step in terms of spelling, punctuation, and grammar. The editing guidelines provided in Cycle 1 could not cover all the students' problems to edit their revised draft. Besides, the example of the sentences in the editing guidelines was different from the students' sentences so that it made them confused to analyze their grammar, punctuation, and spelling mistakes. Moreover, most of them tended to compare their sentences to the examples given in the editing guidelines. However, in Cycle 2, the editing guidelines

Journal on English as a Foreign Language, 10(1), 141-162

Copyright (C) 2020 by JEFL, p-ISSN 2088-1657; e-ISSN 2502-6615 
worked very well to students' activities focusing on the grammar and mechanics.

Also, a mini conference conducted in Cycle 2 could give a positive impact on the students' writings in terms of grammar and mechanics. However, this study was different in the way of making a conference with the study done by Miftah (2015) that students discussed in a mini-conference between teacher and personal students. While the current study shows that discussing with the teacher groups gave a positive contribution to the students' drafts. The grouping was based on the students' problems with their grammar and mechanics in their revised drafts.

The statement on the students' group conference with the teacher was in line with Biber and Conrad's (2009) suggestion. In a major conference teaching might be addressed to a group of several listeners and the group of addressees might be very large but it is possible to identify who they are. Additionally, the teacher was in a unique position to offer feedback since the teacher likely have significant experience with both writing and responses. While peers might struggle to come up with productive responses, the teacher usually have much to say (Berne, 2009). Furthermore, the data obtained from observation revealed that students used the teacher and peer feedback to improve their writings, but the teacher feedback was more likely to be adopted and led to the greater improvements in their writings. It is in line with the study by Nguyen (2018), for the improvement of students' writing skills, it needs to combine teacher and peer feedback to overcome the students' difficulties in writing and to minimize the writing mistakes. However, peer feedback as corrective feedback was associated with a greater degree of student autonomy, and so even in cultures that are said to give great authority to the teacher, there is a role for peer feedback (Pritchard \& Morrow, 2017; Shirotha, 2006; Yang et al., 2006).

In the publishing stage, the two ways of publishing were that the students should read the final version before the class and send them to be uploaded in the teacher's blog. Both activities were useful for the students since the Venn-diagram might be the visualization of the topic discussed in the students' final writing. However, it should be considered the internet access and the students' knowledge of how to read their revised version before the class. Publishing a final draft completed with a Venn-diagram through instructional technology like teacher's blog had changed the teacher's practice in the class to be more motivating (Pitler et al., 2007). It indicates that the language teachers' motivational practice is linked to increased levels of the

Journal on English as a Foreign Language, 10(1), 141-162

Copyright @ 2020 by JEFL, p-ISSN 2088-1657; e-ISSN 2502-6615 
learners' motivated learning behavior as well as their motivational state (Guilloteaux \& Dörnyei, 2008).

Referring to the second findings, it showed that the Venn-diagram strategy could also enhance the students' motivation in writing report text. It could make the students have high motivation in EFL class. They got motivated to show their final writings completed with a colorful Venn-diagram to their peers and the teacher. The report text prepared colored circles that were interesting for them (Wyatt, 2010). The students' responses showed that the students felt easy to write report paragraphs. Additionally, Venn diagram can help students who lack motivation in writing. Some students are not interested to write because it is difficult for them to find the ideas to start their writing. It motivated students can have better performance in writing. This will motivate the students who do not have ideas to start writing by using the ideas that they find together (Mustika \& Adnan, 2019).

To sum up, the use of the Venn-diagram strategy in this present study can improve the students' writing skills and have high motivation during the writing process of report text. First, Venn-diagram is a suitable solution for the students to search for and organize ideas orderly and compile their ideas neatly. It can also reduce the students' habit of using a messy draft to collect their ideas. Second, in writing a report text, it can help students to visualize the concept of writing report texts, and examine the similarities and differences to state and organize their ideas. Third, Venn diagram can assist the students who have lack of motivation in writing so that they can easily find the ideas by filling the diagram to start writing.

\section{CONCLUSION}

The conclusion arrives at the description of how the Venn-diagram strategy can enhance the learners' skills and their motivation in writing report paragraph at the ninth grade of the Islamic secondary school. The teaching procedures consist of five processes - prewriting, drafting, revising, editing, and publishing. First, it is started with the prewriting activities in which the students put thought on paper informally by using a Venn-diagram. The students put the topic going to write, generate topic sentence, and develop supporting details relating to the topic sentence for each circle. Second, it continues to the drafting activities in which the students put their prewriting thoughts into a paragraph of general classification and description. The general classification is taken from the overlapping circle while the description is taken from outside circles. Third, the revising activities cover peer and self-revising.

Journal on English as a Foreign Language, 10(1), 141-162

Copyright (C) 2020 by JEFL, p-ISSN 2088-1657; e-ISSN 2502-6615 
The process focuses on revising the content (which covers the topic sentence and supporting details), the organization (which covers the general classification and description), and the vocabulary (which covers word choice). Fourth, the editing activities focus on editing grammar and mechanical mistakes. The grammar aspect comprises the present tense use and subject-verb agreement, while the mechanics aspect covers spelling, punctuation, and capitalization. All processes of editing activities are assisted through mini group conference. Finally, in the publishing stage, the teacher assigns the students read their final versions of the report paragraph before the class and to send them to be uploaded in the teachers' blog.

\section{DECLARATION OF CONFLICTING INTERESTS}

The authors declared no potential conflicts of interest with respect to the research, authorship, and/or publication of this article.

\section{REFERENCES}

Ahmadi, A., \& Besharati, F. (2017). Web-based versus face-to-face interactionist dynamic assessment in essay writing classrooms - a comparative study. The Journal of Language Learning and Teaching, 7(1), 1-29.

Al-Shaer, I. (2014). Employing concept mapping as a pre-writing strategy to help EFL learners better generate argumentative compositions. International Journal for the Scholarship of Teaching and Learning, 8(2), 1-29. https://doi.org/10.20429/ijsotl.2014.080210

Amjadiparvar, A., \& Zarrï, G. (2019). The relationship between EFL learners' level of language awareness and their motivation and achievement. The Journal of Language Learning and Teaching, 9(2), 37-48.

Berne, J. (2009). The writing-rich high school classroom. London: The Gilford Press.

Biber, D., \& Conrad, S. (2009). Register, genre, and style. Cambridge: Cambridge University Press.

Bidgood, P., Hunt, N., \& Jolliffe, F. (2010). Assessment method in statistical education.West Sussex: Willey.

Brown, H. D. (2007). Teaching by principles: An interactive approach to language pedagogy ( $2^{\text {nd }}$ ed.). New York: Longman.

Byrd, D. R. (2016). Putting the writing process into action in the L2 classroom: Pre-writing techniques that work. The Journal of Language Learning and Teaching, 1(1), 64-77.

Dean, D., \& Grierson, S. (2006). Re-envisioning reading and writing through combined-text picture books. Journal of Adolescent $\mathcal{E}$ Adult Literacy, 48(6), 456-468.

Journal on English as a Foreign Language, 10(1), 141-162

Copyright @ 2020 by JEFL, p-ISSN 2088-1657; e-ISSN 2502-6615 
Djiwandono, M. S. (2008). Tes bahasa: Pegangan bagi pengajar bahasa [Language test: A handbook for language teachers]. Jakarta: PT Indeks.

Friedman, A. (2010). Writing for visual media. Oxford: Library of Congress Cataloging.

Guilloteaux, M. J., \& Dörnyei, Z. (2008). Motivating language learners: A classroom-oriented investigation of the effects of motivational strategies on student motivation. TESOL Quarterly, 42(1), 55-77. https://doi.org/10.1002 ð.1545-7249.2008.tb00207.x

Hanjani, A. M. (2019). Collective peer scaffolding, self-revision, and writing progress of novice EFL learners. International Journal of English Studies, 19(1), 41-57. https://doi.org/10.6018/ijes.331771

Hidayati, K. H. (2018). Teaching writing to EFL learners: An investigation of challenges confronted by Indonesian teachers. Langkawi: Journal of The Association for Arabic and English, 4(1), 21-31. https://doi.org/10.31332/kw.v4i1.772

Junaid, J. (2012). Venn-diagram method for students' ability in writing at intensive English class of UNISMUH Makassar. Exposure: Jurnal Pendidikan Bahasa dan Sastra Inggris, 1(1), 77-103. https://doi.org/10.26618/ejpbi.v1i1.767

Kemmis, S., \& McTaggart, R. (1992). The action research planner (3 ${ }^{\text {rd }}$ ed.). Geelong: Deakin University Press.

Khalili, T. (2018). A qualitative exploration of Iranian learners' writing through face-to-face collaborative writing tasks. The Journal of Language Learning and Teaching, 8(2), 1-11.

Kucan, L., \& Beck, I. L. (2003). Inviting students to talk about expository texts: A comparison of two discourse environments and their effects on comprehension. Reading Research and Instruction, 42(3), 1-31. https://doi.org/10.1080/19388070309558388

Latief, M. A. (2012). Research method on language learning: An introduction. Malang: UM Press.

Malinina, I. (2013). Blended learning as an effective mean to increase motivation for studying English as a second language. 3(1), 244-249.

Miftah, M. Z. (2015). Enhancing writing skill through writing process approach. Journal on English as a Foreign Language, 5(1), 9-24. https://doi.org/10.23971/jefl.v5i1.88

Musa, A., Hussin, S., \& Ho, I. A. (2019). Interaction in academic L2 writing: An analysis of Interactional Metadiscourse Strategies in applied linguistics research articles. 3L The Southeast Asian Journal of English Language Studies, 25(3), 16-32. https://doi.org/10.17576/3L-2019-2503-02 
Mustika, S., \& Adnan, A. (2019). Teaching writing comparison contrast essay by using Venn diagram to second year sudents of English department. Journal of English Language Teaching, 8(3), 380-390.

Nguyen, T. T. L. (2018). The effect of combined peer-teacher feedback on Thai students' writing accuracy. Iranian Journal of Language Teaching Research, 6(2), 117-132.

Pritchard, R. J., \& Morrow, D. (2017). comparison of online and face-to-face peer review of writing. Computers and Composition, 46, 87-103. https://doi.org/10.1016/.compcom.2017.09.006

Rama, A. N. (2018). The effect of Venn diagram to enhance students reading comprehension at the second year of SMP Negeri 1 Wawotobi. Cetta: Jurnal Ilmu Pendidikan, 1(2), 64-75.

Ruskey, F., \& Weston, M. (2011). Spherical venn diagrams with involutory isometries. The Electronic Journal of Combinatorics, 18(1), 1-14. https://doi.org/10.37236/678

Sa'diyah, I. H., \& Cahyono, B. Y. (2019). Effect of Project-Based Learning through blogging on EFL students' writing ability. Journal on English as a Foreign Language, 9(2), 199-216. https://doi.org/10.23971/jefl.v9i2.1341

Samosir, E. A., \& Sibarani, B. (2012). The effect of applying Venn diagram strategy on students' achievement in reading comprehension. Register: Journal of English Language Teaching of FBS-Unimed, 1(1), 1-32. https://doi.org/10.24114/reg.v1i1.337

Shi, L. (1998). Effects of prewriting discussions on adult ESL students' compositions. Journal of Second Language Writing, 7(3), 319-345. https://doi.org/10.1016/S1060-3743(98)90020-0

Shirotha, F. B. (2016). The effect of indirect written corrective feedback on students' writing accuracy. Journal on English as a Foreign Language, 6(2), 101-118. https://doi.org/10.23971 ßefl.v6i2.401

Simpson, J. M. (2006). Feedback on writing: Changing EFL students' attitudes. TESL Canada Journal, 24(1), 96-112. https://doi.org/10.18806/tesl.v24i1.30

Siregar, S. R. (2018). The effect of Venn diagram strategy to students reading comprehension ability at eight grade of SMP Swasta Nurul Ilmi Padangsidimpuan. English Education, 6(1), 39-51. https://doi.org/10.24952/ee k6i1.1217

Sorenson, S. (2010). Webster's new world: Students' writing handbook. Canada: Wiley.

Suherman, A. (2018). Examining relationships between EFL students' learning styles, writing proficiency, and self-assessment. Eternal (English, Teaching,

Journal on English as a Foreign Language, 10(1), 141-162

Copyright @ 2020 by JEFL, p-ISSN 2088-1657; e-ISSN 2502-6615 
Learning, and Research Journal), 4(2), 200-208. https://doi.org/10.24252/Eternal.V42.2018.A5

Syafii, M. L. (2017). BACK and DRAW activities for improving writing skills. Journal on English as a Foreign Language, 7(2), 119-134. https://doi.org/10.23971/jefl.v7i2.501

Tompkins, G. E., \& Hoskisson, K. (1995). Language arts: Content and teaching strategies. New York: Macmillan Publishing Company.

Wyatt, M. J. (2010). Classroom DIY: A practical step-by-step guide to setting up a creative learning environment. Oxon: Routledge.

Yang, M., Badger, R., \& Yu, Z. (2006). A comparative study of peer and teacher feedback in a Chinese EFL writing class. Journal of Second Language Writing, 15(3), 179-200. https://doi.org/10.1016/j.jslw.2006.09.004

\section{Authors' Brief CV}

Muhammad Lukman Syafii is a lecturer of the Accounting Department in Business English of Economics Faculty at Muhammadiyah University of Ponorogo, East Java, Indonesia. He graduated from the State University of Malang, majoring in English Language Teaching. He is one of the members at Language Centre Unit of Muhammadiyah University of Ponorogo.

M. Zaini Miftah is a lecturer of the Department of English Language Education, Faculty of Teacher Training and Education, IAIN Palangka Raya, Indonesia. He graduated from the State University of Malang, majoring in English Language Teaching. He is interested in the research of L2 writing, ELT, TEFL, and Blended Learning.

\section{Appendix: Questionnaire for the students}

\section{Instruction}

The following statements relate to writing activities that are implemented in your class. Please fill in the truth. This is not a test, so your answer will not affect the score at all. Thank you for your cooperation.

1. I enjoy learning to write report texts in English
a. always
b. often
c. sometimes
d. rarely
e. never

2. I feel scared when I get the task of writing a report text in English given by the teacher.
a. always
b. often
c. sometimes
d. rarely e. never

3. I feel compelled to carry out the task of writing a report text in English given by the teacher.

Journal on English as a Foreign Language, 10(1), 141-162

Copyright @ 2020 by JEFL, p-ISSN 2088-1657; e-ISSN 2502-6615 

a. always
b. often
c. sometimes
d. rarely
e. never

4. I complete the task of writing a report text in English given by the teacher if promised to be given a gift.
a. always
b. often
c. sometimes
d. rarely
e. never

5. I feel I have more ability to complete the task of writing report texts in English in class.
a. Always
b. often
c. sometimes
d. rarely
e. never

6. I feel that writing reports texts in English are an easy thing to do.
a. always
b. often
c. sometimes
d. rarely
e. never

7. I feel enthusiastic about doing the task of writing a report text in English in class.
a. always
b. often
c. sometimes
d. rarely
e. never

8. I enjoy writing report texts in English in class.
a. always
b. often
c. sometimes
d. rarely
e. never

9. I feel that the task of writing a report text can improve my English skills.
a. always
b. often
c. sometimes
d. rarely
e. never

10. I feel excited following each process of learning to write report texts in English in class.
a. always
b. often
c. sometimes
d. rarely
e. never

11. If I am given an assignment by the teacher to write a text report, I try to express ideas or initial ideas to start writing.
a. always
b. often
c. sometimes
d. rarely
e. never

12. If I am given an assignment by the teacher to write a report text, I discuss ideas or ideas with friends.
a. always
b. often
c. sometimes
d. rarely
e. never

13. If I am given an assignment by the teacher to write a report text, I discuss ideas or ideas with the teacher.
a. always
b. often
c. sometimes
d. rarely
e. never

14. I am revising the text of my report using the instructions provided by the teacher.
a. always
b. often
c. sometimes
d. rarely
e. never

15. I ask my friend to revise the text of the report that I wrote.
a. always
b. often
c. sometimes
d. rarely
e. never

16. I am editing the use of grammar from the report text that I wrote before it was submitted to the teacher for assessment.
a. always
b. often
c. sometimes
d. rarely
e. never

17. I read the report text that I wrote in front of the class.
a. always
b. often
c. sometimes
d. rarely
e. never

18. I display the report text that I write in a wall magazine.
a. always
b. often
c. sometimes
d. rarely
e. never

19. I get written feedback from the teacher on the text of the report that I wrote.
a. always
b. often
c. sometimes
d. rarely
e. never

20. I got a specific strategy for writing a report text on learning to write.
a. always
b. often
c. sometimes
d. rarely
e. never

Journal on English as a Foreign Language, 10(1), 141-162

Copyright @ 2020 by JEFL, p-ISSN 2088-1657; e-ISSN 2502-6615 